\title{
NUCLEOLAR ACTIVITY OF LYMPHOCYTES IN HEALTHY AND LEUKOTIC CATTLE
}

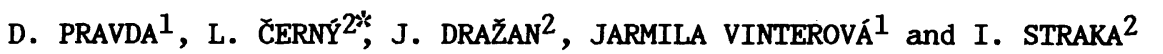 \\ ${ }^{1}$ University of Agriculture, 61300 Brno and \\ 2 University of Veterinary Science, 61242 Brno
}

Received November 10, 1987

A b s t r a c t

P r a v d a D., L. $\check{c}$ e $r n \dot{y}, \quad J . \quad$ D r a ž a $n, \quad J$ a r$\mathrm{m}$ i 1 a $\mathrm{v}$ i $\mathrm{nt}$ e $\mathrm{r}$ o vá, I. $\mathrm{s} \mathrm{t} \mathrm{r}$ a $\mathrm{k}$ a: Nucleolar Activity of Lymphocytes in Healthy and Leukotic Cattle. Acta vet. Brno, 57, 1988:123-131.

In blood smears of healthy and leukotic dairy cows, the numbers and ratio of individual types of lymphocyte nucleoli were determined using the nucleolar test according to $\mathrm{S} \mathrm{m} \mathrm{e}$ $t$ a $n$ a (1986). The following types of nucleoli were studied: compact (active), ring-shaped (resting), and micronucleoli (termina1).

Using Student $s$ t-test, no significant difference was found in the actual numbers of compact nucleoli between the group of leukotic and healthy dairy cows. The retardation of compact nucleoli in lymphocytes of leukotic animals is discussed with regard to their persistence and viability in circulation as compared with findings in healthy animals.

EBL, B-1ymphocytes, nucleoproteins, nucleoli.

Enzootic bovine leukemia (EBL) and its contagious character are well-known from epizootiological studies published at the beginning of this century. Under conditions of natural infection, the onset of the disease is asymptomatic with subsequent occurrence of a chronic and persisting accumulative lymphocytosis; the dairy cow is infected for lifetime, including the subsequent formation of lymphomas ( $B$ e $n$ d $i x-$ e $n$ 1965).

The disease is caused by a retrovirus, viz. bovine leukemia virus (BLV) (M i $11 \mathrm{e} \mathrm{r}$ et al. 1969; $\mathrm{K}$ a $\mathrm{w} \mathrm{a} \mathrm{k} \mathrm{a} \mathrm{m} \mathrm{i} \mathrm{et} \mathrm{al.} \mathrm{1970).} \mathrm{However,} \mathrm{the}$ leukocytogenesis caused by the BLV has not been fully explained as yet ( $\mathrm{K}$ e $\mathrm{t} t \mathrm{~m}$ a $\mathrm{n}$ et al. 1978; $\mathrm{D}$ e $\mathrm{s} \mathrm{ch} \mathrm{h} \mathrm{m} \mathrm{s}$ et a1. 1981). The virus is exogenous, but it does not show any indication of serological similarity with other retroviruses of similar type from other species of vertebrates ( F e r r e r 1980).

*L. Černý deceased in September 1989. 
Recently, however, it was found that the human T-cell leukemia virus, Type I (HLTV-I) causing the T-cell leukemia lymphoma in adults ( $P \circ p \circ \mathrm{v} i \mathrm{c}$ et al. 1982) and the virus (HLTV-II) causing $a$ benign $T$-cell form of hairy cell leukemia ( $\mathrm{h}$ e $\mathrm{n}$ et al. 1983) show, as well as BLV, many common structural and biological properties which differentiate them from other members of retroviral family ( $\mathrm{r}$ a $i \mathrm{~g}$ et a1. 1986).

Under conditions of natural and/or experimental infection with the BLV in cattle and sheep only B-lymphocytes are involved ( $P$ a $u 1$ et al. 1977; $\mathrm{K}$ e $\mathrm{n}$ y o $\mathrm{n}$ et al. 1977). These lymphocytes, including lymphocytes present in blood circulation, are competent to support replication of the BLV and to synthesize specific antibodies. Thus it is possible to raise a question whether we can detect changes in functional activities of exposed lymphocytes of peripheral circulation in their dynamic nuclear organelles, i. e. nucleoli, under the influence of BLV infection. Generally the type of nucleolus is conditioned by the physiological status of the cell in the course of its life cycle in relation to ribosomal biogenesis ( $\mathrm{H}$ a d $j \mathrm{i} \circ \mathrm{l} \circ \mathrm{v}$ 1985).

In this study we compared the structural organization and distribution of nucleoprotein structures of nucleoli in blood lymphocytes of leukotic and healthy dairy cows and classified the observed nucleoli according to $\mathrm{S} m$ e $\mathrm{t}$ a $\mathrm{n}$ a $\mathrm{s}$ system (1986).

\section{Materials and Methods}

\section{Dairy cows}

In this study dairy cows of Danish Red and Black-Pied Lowland breeds aged 3 to 10 years were observed. They originated from three localities - isolates for leukotic cows in which leukosis was repeatedly diagnosed both serologically and hematologically. Control animals were serologically and hematologically negative when tested for response to BLV. Nosocomial infections caused by IBR or parainfluenza III viruses and mastitis were not diagnosed.

\section{Hematological examination}

Blood for the determination of leukocytes was sampled from v. jugularis using a HEMOS blood sampling set with an adjusted amount of sodium salt EDTA; the final concentration of anticoagulants in blood samples was $0.5 \%$.

To determine the total number of leukocytes, the Buirger $s$ flask method was used and the leukocytes in Türk's solution were counted in 100 large squares of Bürker $s$ chamber using a modification for a high degree of accuracy ( $\mathrm{r}$ a $\mathrm{v} d \mathrm{a}$, unpublished data).

\section{Blood smears}

Dry smears were made immediately after blood sampling and stained within 12 hours. The stock solution containing $0.5 \mathrm{~g}$ of toluidine blue in $100 \mathrm{~m} 1$ of $10 \%$ ethanol was diluted (1:12) with McIlvain s buffer which was always freshly prepared. Preparations were stained for 10 minutes at room temperature, thereafter the stain was poured off and the preparation was dried in vertical position. Preparations were examined under a NFPK microscope using an oil immersion lens. 
Nucleoli counted in lymphocytes were classified as follows ( $\mathrm{m}$ e $\mathrm{t}$ an a 1986):

1. compact - with a relatively uniform distribution of ribonucleoprotein components; they were assumed active in terms of transcription and maturing of ribosomal RNA.

2. ring-shaped - ribonucleoprotein structures were present in the form of a ring only in the peripheral part. This ring encircled a filamentous center containing DNA and proteins. These nucleoli showed a decreased activity in transcription of ribosomal RNA, however, it was reversible. They were classified as potentially active nucleoli.

3. micronucleoli - final irreversible developmental stage of the nucleolus, inactive.

The differential count of leukocytes was carried out using blood smears stained in a standard manner and the leukogram was obtained from 200 cells counted: the actual number of lymphocytes was then extrapolated.

\section{Results}

The morphological characteristics of lymphocyte nucleoli (as detected in blood smears and visualized after staining with toluidine blue according to Smetana) are presented in Table 1 together with proportions of nucleolar types found in individual dairy cows. In this table a group of 19 leukotic cows is presented with up to 25000 lymphocytes per $1 \mathrm{~mm}^{3}$ of blood. In group 2 animals with 26000 to 64000 lymphocytes per $1 \mathrm{~mm}^{3}$ of blood are included. The group had 11 cows. In group 3, 13 healthy cows are included.

In Table 2 a group of 13 healthy cows is presented with lymphocyte counts ranging from 2000 to 5000 per $1 \mathrm{~mm}^{3}$ of blood.

These three groups were statistically analyzed and compared with regard to the actual number of the individual nucleoli types:

a. The $t$-test revealed no significant difference $(P>0.05)$ between leukotic and healthy dairy cows in numbers of compact and ring-shaped nucleoli.

b. a significant difference $(P<0.05)$ in the actual numbers of compact nucleoli was found between Group 1 of leukotic cows and that of healthy animals.

c. a significant difference $(P<0.01)$ in the actual numbers of compact nucleoli was found between Group 2 of leukotic dairy cows and that of healthy animals. 
d. there was no marked difference between Group 1 and 2 of leukotic dairy cows in the actual numbers of compact nucleoli.

Based on this analysis, it is possible to characterize the dynamics of changes in the functional activity of lymphocyte nucleoli (compact nucleoli $\rightarrow$ ring-shaped nucleoli); this can be documented using calculations of frequency rations of the individual types of nucleoli.

In the group of healthy cows and in Group 1 of leukotic animals, the frequency ratio of their micronucleoli and ring-shaped nucleoli is nearly identical.

In Group 2 of leukotic dairy cows with a high number of lymphocytes, the frequency ratio of their compact and ring-shaped nucleoli is nearly by $30 \%$ lower than in the group of healthy animals.

This difference indicates that the dynamics of change of compact nucleoli into ring-shaped ones is significantly inhibited in lymphocytes of leukotic dairy cows.

\section{Discussion}

In the vascular bed, cattle lymphocytes are predominantly in the $G_{0}$ phase excluding the time interval given by the primary or secondary immune response, so that the synthesis of RNA and proteins is exceedingly slow in these cells. In healthy dairy cows, about $0.5 \%$ of lymphocytes are in the synthetic (S) phase. In leukotic animals the number of lymphocytes in the S-phase increases proportionally to the number of persisting lymphocytes ( $\check{C}$ e $r n \dot{y}$ et al. in press). This would explain the existence of two groups of leukotic animals, i. e. with lower and higher numbers of lymphocytes. There was no marked statistical difference in actual numbers of compact nucleoli between these two groups.

As far as clinical and epizootiological examinations were concerned, the cows under study were not under the antigenic effect of vaccines and/or nosocomial infections from the group of herpetic bovine viruses, parainfluenza III virus or trypanosomes, the antigens of which stimulate 
Table 2

Lymphocyte counts in healthy dairy cows

\begin{tabular}{|c|c|c|c|c|c|c|c|c|c|}
\hline \multirow{3}{*}{$\begin{array}{l}\text { Cow } \\
\text { No. }\end{array}$} & \multirow{3}{*}{$\begin{array}{l}\text { Leuko- } \\
\text { cytes } \\
.10^{9} / 1\end{array}$} & \multirow{3}{*}{$\begin{array}{c}\text { 1ympho- } \\
\text { cytes } \\
.10^{9} / 1\end{array}$} & \multicolumn{5}{|c|}{ nucleoli } & \multicolumn{2}{|c|}{ micronucleoli } \\
\hline & & & & compact & & ring & haped & & \\
\hline & & & $\%$ & $\%$ & $.10^{9} / 1$ & $\%$ & $.10^{9} / 1$ & $\%$ & $.10^{9} / 1$ \\
\hline 1 & 8.25 & 3.50 & 41.30 & 3.17 & 0.11 & 36.50 & 1.27 & 60.31 & 2.11 \\
\hline 2 & 8.40 & 4.28 & 50.9 & 8.60 & 0.36 & 33.11 & .1 .41 & 58.27 & 2.49 \\
\hline 3 & 8.50 & 5.14 & 60.4 & 9.21 & 0.47 & 26.24 & 1.34 & 64.53 & 3.31 \\
\hline 4 & 7.95 & 4.09 & 64.2 & 3.40 & 0.13 & 30.61 & 1.25 & 65.98 & 2.69 \\
\hline 5 & 8.55 & 5.17 & 60.8 & 7.69 & 0.39 & 29.23 & 1.51 & 63.07 & 3.26 \\
\hline 6 & 9.10 & 3.50 & 38.5 & 9.52 & 0.33 & 36.73 & 1.28 & 53.74 & 1.88 \\
\hline 7 & 7.00 & 2.27 & 39.5 & 14.61 & 0.33 & 26.92 & 0.61 & 58.46 & 1.32 \\
\hline 8 & 10.20 & 4.74 & 47.4 & 8.33 & 0.39 & 14.81 & 0.70 & 76.85 & 3.64 \\
\hline 9 & 5.70 & 2.08 & 41.6 & 3.22 & 0.63 & 30.64 & 0.63 & 62.12 & 1.37 \\
\hline 10 & 8.30 & 3.85 & 46.1 & 12.50 & 0.45 & 36.02 & 1.38 & 51.47 & 1.98 \\
\hline 11 & 4.25 & 2.01 & 52.2 & 7.25 & 0.24 & 20.96 & 0.42 & 71.47 & 1.43 \\
\hline 12 & 7.90 & 4.30 & 53.7 & 9.02 & 0.38 & 24.06 & 1.03 & 66.91 & 2.87 \\
\hline 13 & 7.05 & 2.23 & 32.2 & 15.78 & 0.35 & 24.06 & 0.53 & 60.15 & 1.34 \\
\hline
\end{tabular}

blood lymphocytes to an extraordinary degree. This means that under the given conditions the observed frequencies of individual types of nucleoli can be associated with the pathogenesis caused by the BLV.

The fact that the antigenic stimulation shows a considerable effect on the activity of lymphocytes has been demonstrated also from experiments with mice: an i.p. application of sheep lymphocytes resulted in a significant increase of numbers of compact nucleoli in blood lymphocytes during the primary immune response ( $K$ o $r$ č á $k \quad 0 \quad v$ á et al. 1969).

Our examination was carried out only once; because of technical reasons, it could not be repeated after a certain time interval to reveal either fluctuation or stability of the findings regarding nucleolar types. Preliminary experiments to demonstrate the BLV in short-term cultures of leukotic cattle lymphocytes showed that, even under nearly identical conditions, it was not possible to obtain the BLV from two subsequent blood samples of one leukotic dairy cow: in one experiment with radioactive uridine labelling the yield was zero ( $\mathrm{Z}$ á $\mathrm{v}$ a $d$ a et al. 1979). This indicates also the complexity of the in vivo situation 
regarding the regulatory mechanisms affecting the target cells, i. e. B-lymphocytes which are the producers of BLV.

In cattle, it is not known how the aforementioned forms of nucleoli correspond with the intensity of transcription of ribosomal RNA ( $\mathrm{s}$ e $t \mathrm{a} a$ and $B u s c h$ 1974).

Regarding the inhibition of transformation of active nucleoli into resting ones it is possible to say that, in the group of dairy cows with a high number of lymphocytes, these lymphocytes with active nucleoli may form a group of cells with a longer life cycle than in the group of healthy animals (D a $\mathrm{m} \mathrm{e} \mathrm{s} \mathrm{he} \mathrm{k} \mathrm{1967;} \mathrm{T} \mathrm{he} \mathrm{m} \mathrm{l} \mathrm{et} \mathrm{al.} \mathrm{1973).} \mathrm{As} \mathrm{far}$ as the nucleolar activity and the associated transcription of ribosomal RNA are concerned, it should be mentioned that nucleolar organizers were recently found on chromosomes 2, 3, 4, 11 and 28 ( $M$ a y r et al. 1981). However, it is not known which of these nucleolar organizers, localized on corresponding chromosomes, control the formation of a nucleolus in a given cell.

Nukleolární aktivita krevních lymfocytů

u zdravých a leukózních dojnic

Nukleolárním testem dle Smetany byl v lymfocytech z krevních nátěrů zdravých a leukózních dojnic stanoven počet a poměr jednotlivých typů jadérek: kompaktních (aktivních), prsténčitých (klidoví̛ch), mikronukleolů (terminálních). Pomocí t-testu byl prokázán významný rozdíl mezi absolutními četnostmi kompaktních jadérek u souboru leukózních dojnic oproti souboru dojnic zdravých. Je diskutována retardace kompaktních jadérek $\mathrm{v}$ lymfocytech leukóznich dojnic vzhledem $k$ prolongaci jejich prodlevy a životnosti $v$ krevním oběhu oproti lymfocytům zdravých zvírat.

Ядрьшковая активность лимфоцитов крови здоровых и лейкозных дойных коров

Нуклеолярным тестом по Сметане в лимфоцитах мазков крови здоровых и лейкозных дойных коров опре- 
деляли численность и соотношение отдельных типов ядрышек: компактных (активных), кольцевидных (в состоянии покоя), микронуклеолей (терминальных) . С помощью теста была Установлена значимая разница между абсолютной частотой компактных ядрышек У совокупности лейкозных дойных коров по сравнению С группой здоровых молочных коров. Обсуждается замедление компактных ядрышек в лимфоцитах лейкозных дойных коров, учитывая увеличение их выдержки и жизнеспособность в кровообращении по сравнению с лимфоцитами здоровых животных.

\author{
References
}

BENDIXEN, H. J.: Bovine enzootic leukosis. Adv. veter. Sci. comp. med., 10, 1965: 129

CHEN, I. S. Y. - QUAN, S. G. - GOLDE, D. W.: Human T-ce11 leukemia virus type transforms normal human lymphocytes. Proc. nat. Acad. Sci., $\underline{80}$, 1983: 7006

CRAIG, A. - ROSEN, J. - SODROSKI, J. G. - KETTMANN, R. - HASELTINE, W. A.: Activation of enhancer sequences in type II leukemia-virus long terminal repeats human $\mathrm{T}-\mathrm{ce} 11$ leukemia virus and bovine leukemia virus-associated transacting regulatory factors. J. Viro1., 57, 1986: 738

ČERNÝ, L. - PRAVDA, D.: ${ }^{3} \mathrm{H}$-thymidine labeling lymphocytes in cultures of leukotic and healthy cattle. In press.

DAMESHEK, W.: Chronic lymphotic leukemia as accumulative disease of immunologically incompetent lymphocytes. Blood, 29, 1967: 566

DESCHAMPS, J. - KETTMANN, R. - BURNY, A.: Experiment with cloned complete tumor-derived bovine leukemia virus information proved that the virus is totally exogenous to its target animal species. J. virol., 40, 1981: 605

FERRER, J. F.: Bovine 1ymphosarcoma. Adv. veter. Sci. comp. Med., 24, 1980: 1

HADJIOLOV, A. A.: Ribosome biogenesis in the life cycle of normal and cancer cells in the nucleolus and ribosome biogenesis. Springer Verlag Berlin, 1985.

KAWAKAMI, T. G. - MOORE, A. L. - THEILENN, G. H. - MANN, R. J.: Comparison of virus-like particles from leukotic cattle to feline leukosis virus. Bib1. hematol., 36, 1970: 471

KENYON, S. J. - PIPER, C. E.: Properties of density gradient-fractionated peripheral blood leukocytes from cattle infected with bovine leukemia virus. Infect. Immuno1., 16, 1977: 898

KETTMANN, R. - BURNY, A. - CLEUTER, Y. - GHYSDALE, J. - MAMMERICKX, M.: Distrubition of bovine leukemia proviral DNA sequences in tissue of animals with enzootic bovine leukosis. Leukemia Res., 2, 1978: 23

KORČÁKOVÁ, L. - HOLUB, M. - NOUZA, K. - DRÁBER, P.: Response of blood leukocytes to an intraperitoneal immunization in normal and leukopenic mice with the nu-gene. Fo1. biol., 91, 1969: 381 
MAYR, B. - CZAKER, R.: Variable positions of nucleolus organizer regions in Bovidae. Experientia, 37, 1981: 564

MILLER, J. M. - MILLER, M. D. - OLSON, C. - GILLETE, K. G.: Virus-1ike particles in phytohemagglutinin-stimulated lymphocyte cultures with reference to bovine 1ymphosarcoma. J. Nat1. Cancer Inst., 43, 1969: 1297

PAUL, P. S. - POMEROY, A. E. - CASTRO. A. E. - JOHNSON, D. W. MUSCOPLAT, C. C. - SORENSEN, D. K.: Detection of bovine leukemia virus in B-1ymphocytes by syncytia induction assay. J. Nat1. Cancer Inst., 59, 1977: 1269

SMETANA, K. - BUSCH, H.: The nucleolus and nucleolar DNA. In The Cell Nucleus (Busch, H. Ed.) Vo1. I, 1974: 75

SMETANA, K.: Nucleolus, Cytológia, Ed. A. Bozner, Osveta Bratislava, 1986, $160 \mathrm{p}$.

THEML, H. - TREPEL, F. - SCHICK, P. - KABOTH, W. - BEGEMANN, H.: Kinetics of 1ymphocytes in chronic 1ymphocytic leukemia: Using continuous ${ }^{3} \mathrm{H}$-thymidine infusion in two patients. Blood, 24, 1973: 623

ZÁVADA, J. - ČERNÝ, L. - ZÁVADOVÁ, Z. - BOZOÑOVÃ, J. - ALTSTEIN, A. D.: A rapid neutralization test for antibodies to bovine leukemia virus with use of rhabdovirus pseudotypes. J. nat. Cancer Inst., 62, 1979: 95-101 